\title{
Mapping the Chromosome of Yersinia pseudotuberculosis by Interrupted Mating
}

\author{
By P. C. MCMAHON \\ Microbiological Research Establishment, Porton Down, Salisbury, Wiltshire
}

(Received I8 January 1973; revised 2 March 1973)

SUMMARY

By interrupting matings at different times, the sequential transfer of selected and unselected markers to recipient bacteria was followed in Yersinia pseudotuberculosis. Under the best mating conditions employed, the earliest marker was transferred within 13 min and the latest within 98 min of impinging mating mixtures on membranes. All tested donor markers appeared in recombinants. A genetic map based on the entry times of markers indicated a single linkage group showing much similarity to that of Escherichia coli. The high frequency donor transferred markers in a clockwise direction, its origin corresponding to a point near $60 \mathrm{~min}$ on the E. coli map.

\section{INTRODUCTION}

Other workers have demonstrated fertility in Yersinia (formerly Pasteurella) pseudotuberculosis group D (Lawton, Morris \& Burrows, 1968; Morris \& Burrows, 1968) and shown that genes could be transferred at a frequency of about $\mathrm{IO}^{-4} /$ donor bacterium mediated by the $\mathrm{F}$ lac episome which had been introduced from Escherichia coli $\mathrm{K} I 2$ (strain 23.10S). A study of the same system led Lawton \& Stull (1971) to conclude that there was possibly more than one chromosome in $Y$. pseudotuberculosis group D.

Later, a high frequency donor strain (MRE 4OI8) was obtained in Yersinia pseudotuberculosis group A (McMahon, I97I) which could transfer early markers at a frequency of about $\mathrm{I} / 25$ donor bacteria. Furthermore, genes were transferred with different frequencies suggesting a linear order and recombinants were obtained for all genes examined.

The present paper is an extension of that work and presents quantitative results and map positions for a number of markers obtained by the interrupted mating technique (Wollman \& Jacob, 1955, 1958). A genetic map of Yersinia pseudotuberculosis was constructed from the entry times of markers and is compared with that of Escherichia coli.

\section{METHODS}

Strains. The genotypes and origins of the strains of Yersinia pseudotuberculosis group A used were as described by McMahon (1971); the same high frequency donor, MRE 4018, was used in all crosses in the present work. In addition, the following strains were used: MRE 4200, a colonially opaque derivative of MRE 4176 which had the same genotype as MRE 4I76; MRE 4I97, str-23 from MRE 4OI8; MRE 4198, str-24 from MRE 4OI8. Abbreviations designating genotypes and phenotypes of strains follow the recommendations of Demerec, Adelberg, Clark \& Hartman (I968).

The media and buffer were as described by McMahon (1971). Selective media consisted of minimal agar (MA) supplemented with the growth factors of the recipient strain, other 
Table I. Comparison of agitation methods for effective separation of mating pairs in the cross MRE $40 \mathrm{I} 8 \times$ MRE 4176

Donor $\left(1 \times 10^{8}\right)$ and recipient $\left(3 \times 10^{8}\right)$ bacteria were impinged as a mixture on to a number of membranes and incubated for different periods at $28^{\circ} \mathrm{C}$. The bacteria were removed from the membranes by hand-shaking in buffer, diluted and plated on different selective media so that approximately $1.5 \times 10^{4}$ donor and $4.5 \times 10^{4}$ recipient bacteria were seeded per plate; the suspensions were then agitated with a Towers Vibrator and plated in a similar fashion. The recombinants were recorded after $40 \mathrm{~h}$ at $28^{\circ} \mathrm{C}$.

\begin{tabular}{|c|c|c|c|c|c|c|}
\hline \multirow{2}{*}{$\begin{array}{c}\text { Sample } \\
\text { time (min) }\end{array}$} & \multirow{2}{*}{$\begin{array}{l}\text { Agitation } \\
\text { method }\end{array}$} & \multicolumn{3}{|c|}{$\begin{array}{c}\text { Recombinants/plate } \\
\text { selected marker }\end{array}$} & \multicolumn{2}{|c|}{$\begin{array}{l}\% \text { Unselected markers } \\
\text { among selected } \mathrm{Met}^{+}\end{array}$} \\
\hline & & $\mathrm{Met}^{+}$ & Pro $^{+}$ & $\mathrm{His}^{+}$ & Pro $^{+}$ & $\mathrm{His}^{+}$ \\
\hline 100 & Hand & I 26 & $2 \mathrm{I}$ & 2 & 6 & I \\
\hline 100 & Towers & 43 & 0 & 0 & 0 & 0 \\
\hline I 10 & Hand & 523 & 127 & I 2 & 17 & 7 \\
\hline IIO & Towers & 85 & 0 & 0 & 0 & 0 \\
\hline
\end{tabular}

than that of the selected marker(s). The final concentrations $(\mu \mathrm{g} / \mathrm{ml})$ of the growth factors were: bases, 10; L-amino acids, 20; DL-amino acids, 40.

Interrupted mating. Crosses were carried out on membranes (McMahon, 1971), a separate one being used for each sample. Except for earlier experiments at $28{ }^{\circ} \mathrm{C}$, all matings were carried out in a $37^{\circ} \mathrm{C}$ hot room. The media, glassware and membrane holders were warmed in a hot room prior to use.

Mixtures of donor and recipient bacteria $\left(4 \times 10^{7}\right.$ donor and $1 \cdot 2 \times 10^{8}$ recipient) were incubated with rotation in a $37^{\circ} \mathrm{C}$ hot room for $\mathrm{I}$ h to bring them into log-phase growth; mating does not take place during this pre-incubation period (McMahon, 1971). Samples $(2 \mathrm{ml})$ were impinged on to a number of membranes in the shortest practicable time, the time of impingement being taken as time $o$. At different intervals, individual membranes were blended for I min in Io $\mathrm{ml}$ buffer containing five large glass beads using a Towers Vibrator (J. W. Towers \& Co Ltd, Widnes, Lancashire). The blended samples were diluted so that approximately $\mathrm{I} .5 \times 10^{4}$ donor and $4.5 \times 10^{4}$ recipient bacteria were seeded $/$ plate from each sample on to the different selective media. The plates were incubated at $28{ }^{\circ} \mathrm{C}$ for 2 to 3 days. Controls consisted of plating similar numbers of donor and recipient (taken from the mating mixture just prior to impingement) on similar selective media.

The number of recombinants obtained from each sample (for a particular marker) was plotted against time. The linear part of the plot was extrapolated on to the time axis to give an intercept value, which was taken as the earliest time of entry of the marker.

Purification and analysis of recombinants. The methods were those described by McMahon (I97I). Samples of purified selected recombinants were routinely checked on appropriate media, and where possible, a minimum of Ioo were analysed for unselected markers.

\section{RESULTS}

Separation of mating pairs

It has already been established (McMahon, 1971) that donor and recipient bacteria when plated on selective media in the same numbers as outlined under Methods, did not mate on the plate. Recombinant-free platings from interrupted mating experiments were only obtained when either a Waring blender or a Towers Vibrator was used to separate the mating bacteria. $\mathrm{Met}^{+}, \mathrm{Pro}^{+}$and $\mathrm{His}^{+}$recombinants were obtained from hand-shaken samples in the 


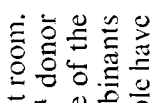

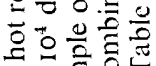

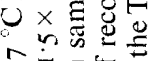
的标手

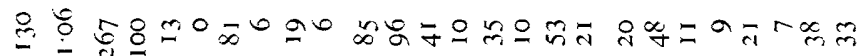

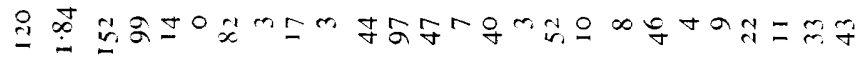

음

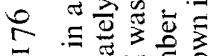

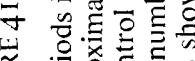

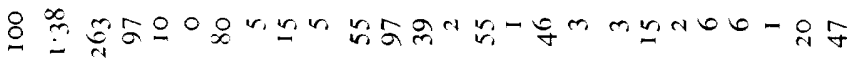

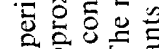

的

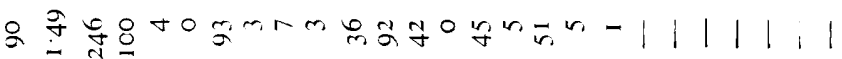

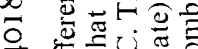

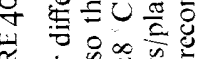

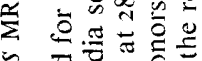

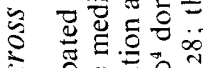

S

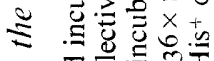

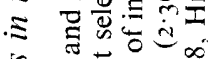

它

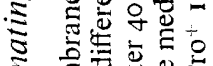

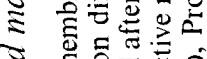

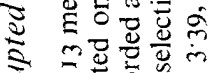

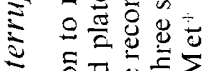

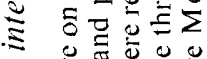

‡.

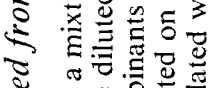

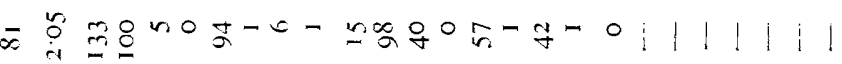

영요

\&

ir.

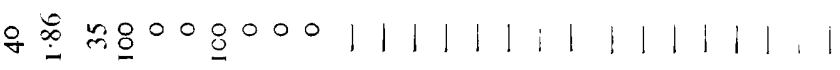

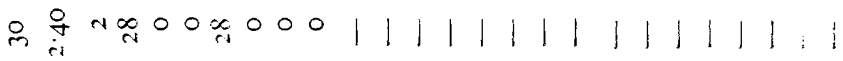

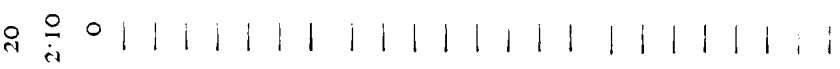

$=\frac{n}{i} 0111111111111111111111,1$
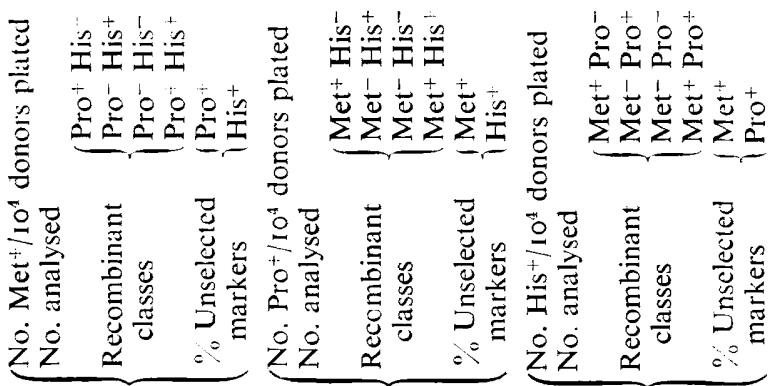

ऽ

可 $\times$

से

i

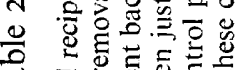

है
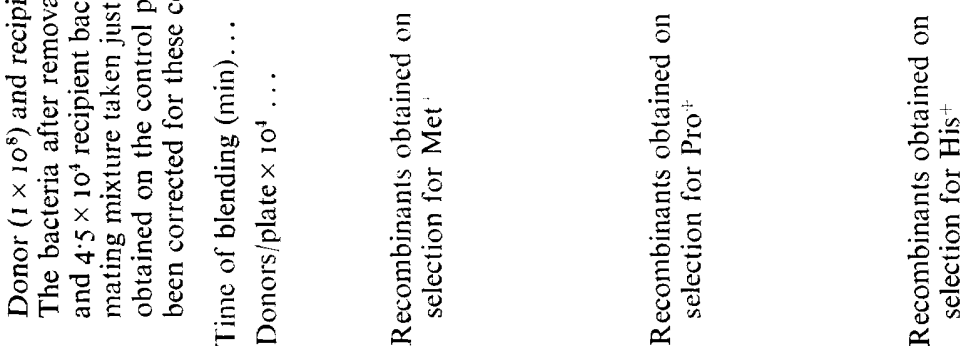


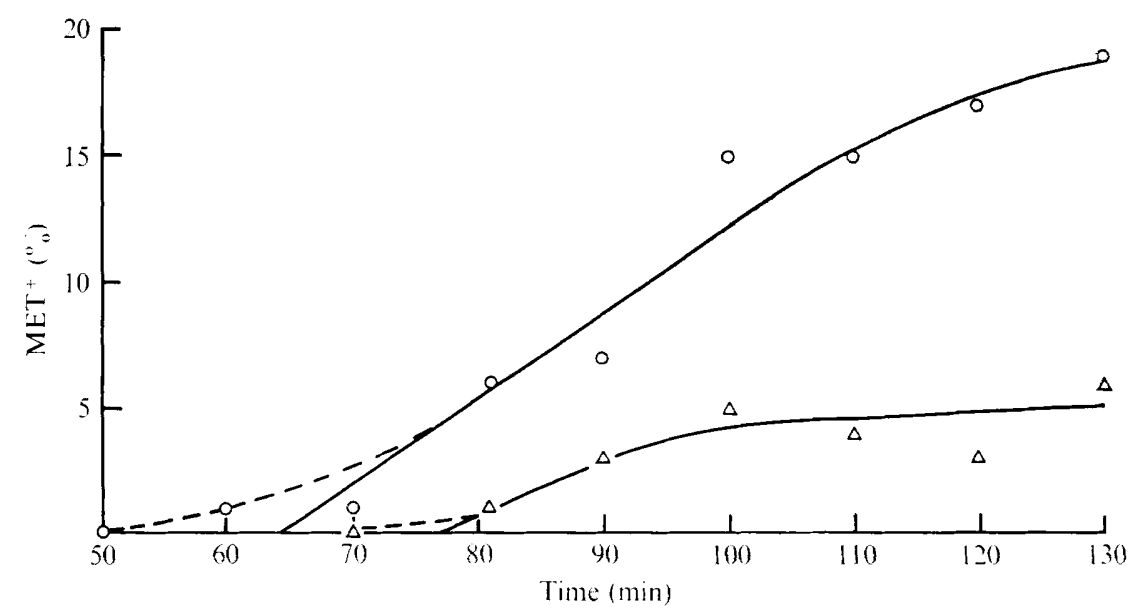

Fig. I. Percentages of unselected Pro $(O-O)$ and His $^{+}(\triangle-\triangle)$ markers among selected Met $^{-}$ markers relative to time of mating.

cross MRE $4018 \times$ MRE 4176 (Table I). Blending these samples with a Towers Vibrator reduced the number of $\mathrm{Met}^{+}$obtained and prevented the transfer of pro-II and his-2I. Since no loss in viability was detected following this treatment, it was inferred that blending could disrupt mating pairs and prevent the transfer of the more distal markers, pro- $I I$ and his- $2 I$.

\section{Interruption of mating at $37^{\circ} \mathrm{C}$}

As reported previously (McMahon, I97I), marker transfer frequencies were increased about fourfold when matings were carried out at $37^{\circ} \mathrm{C}$ instead of $28{ }^{\circ} \mathrm{C}$. In addition to obtaining these higher frequencies from interrupted matings at $37^{\circ} \mathrm{C}$, selected $\mathrm{Met}^{+}$was recovered about 50 min earlier than from matings at $28^{\circ} \mathrm{C}$. When all operations (except blending and plating), were carried out in a $37^{\circ} \mathrm{C}$ hot room, entry times were further reduced by about $15 \mathrm{~min}$. Under the same conditions, selected $\mathrm{Pro}^{+}$was recovered about 80 min earlier and selected $\mathrm{His}^{+}$about II 5 min earlier.

An interrupted mating experiment was carried out under these improved conditions using MRE 4OI 8 and MRE 4I76; mating was allowed to proceed up to I $30 \mathrm{~min}$, an individual membrane being taken every Io min for analysis (Table 2). It is apparent from these results that the three donor markers were transferred into the recipient at different times, the approximate times of entry being $30 \mathrm{~min}$ for $\mathrm{Met}^{+}, 60 \mathrm{~min}$ for $\mathrm{Pro}^{+}$and $80 \mathrm{~min}$ for $\mathrm{His}^{+}$. The recombinant classes obtained were those that would be expected from a linear transfer of genes: an increase with time for markers more distal than the selected marker and a fairly constant number of markers which were proximal to that selected. The percentages of unselected distal markers among selected $\mathrm{Met}^{+}$are shown as a function of time in Fig. I, the intercepts on the time axis being in good agreement with the estimates of the times of entry of these markers deduced from direct selection. None of the recombinants examined inherited $\mathrm{Lac}^{+}$. 
Table 3. Time intercept values obtained from interrupted matings with donor MRE 4018

Donor $\left(1 \times 10^{8}\right)$ and recipient $\left(3 \times 10^{8}\right)$ bacteria were impinged as a mixture on to membranes and incubated for different periods in a $37^{\circ} \mathrm{C}$ hot room. The bacteria after removal from membranes and blending were diluted and plated on different selective media so that approximately $1.5 \times 10^{4}$ donor and $4.5 \times 10^{4}$ recipient bacteria were seeded per plate. The recombinants were recorded and picked for analysis after 2 days of incubation at $28 \mathrm{C}$. Time intercepts were obtained for selected markers by plotting their increase in number against time and extrapolation on to the time axis; intercepts were obtained for unselected markers by plotting and extrapolating the numbers of unselected markers, associated with a selected marker, against time.

\begin{tabular}{|c|c|c|c|c|}
\hline \multirow{2}{*}{$\begin{array}{l}\text { Recipient } \\
\text { strain } \\
\text { (MRE no.) }\end{array}$} & \multirow{2}{*}{$\begin{array}{l}\text { Selected } \\
\text { marker }\end{array}$} & \multirow{2}{*}{$\begin{array}{l}\text { Timed } \\
\text { marker }\end{array}$} & \multicolumn{2}{|c|}{ timed marker (min) } \\
\hline & & & Selected & Unselected \\
\hline \multirow[t]{2}{*}{4177} & met-2 & $t y r-7$ & 一 & 67 \\
\hline & $t y r-7$ & $t y r-7$ & 71 & - \\
\hline 4177 & $t y r-7$ & $h i s-22$ & - & 77 \\
\hline 4178 & his-22 & $h i s-22$ & $8 \mathrm{I}$ & - \\
\hline \multirow[t]{2}{*}{4179} & leu-5 & $h i s-22$ & - & 78 \\
\hline & $h i s-22$ & $h i s-22$ & 81 & - \\
\hline \multirow[t]{3}{*}{4179} & letu-5 & leu-5 & 44 & - \\
\hline & met -2 & leu-5 & - & $4 I$ \\
\hline & leu-5 & leu-5 & 46 & - \\
\hline \multirow[t]{2}{*}{4180} & met-2 & met-2 & 28 & - \\
\hline & $i l v-4$ & met-2 & - & $\mathrm{P}$ \\
\hline \multirow[t]{2}{*}{4183} & $m e t-2$ & $m e t-2$ & $3 I$ & - \\
\hline & pur-I 5 & met-2 & - & 28 \\
\hline 4155 & met-2 & met-2 & 32 & - \\
\hline \multirow[t]{2}{*}{4194} & met-2 & $m e t-2$ & 34 & - \\
\hline & $m e t-2$ & met-2 & 26 & - \\
\hline 4185 & $i l v-3$ & $m e t-2$ & 一 & $\mathbf{P}$ \\
\hline 4188 & met-2 & $m e t-2$ & 32 & - \\
\hline 4179 & $m e t-2$ & met-2 & $3 r$ & - \\
\hline 4186 & $m e t-2$ & met-2 & 31 & - \\
\hline 4200 & $m e t-2$ & $m e t-2$ & 29 & - \\
\hline \multirow[t]{2}{*}{4180} & ilv-4 & $i l v-4$ & 36 & - \\
\hline & $m e t-2$ & $i l v-4$ & - & $\mathrm{P}$ \\
\hline $418 I$ & $m e t-2$ & $p y r-I$ & - & 56 \\
\hline 4182 & $m e t-2$ & $p y r-I$ & - & 54 \\
\hline \multirow[t]{3}{*}{4200} & met-2 & pro-II & - & 54 \\
\hline & pro-II & pro-II & 54 & $\cdots$ \\
\hline & pro-II & pro-II & 55 & 一 \\
\hline \multirow[t]{3}{*}{4200} & pro-II & $h i s-2 I$ & - & 82 \\
\hline & $h i s-2 I$ & $h i s-2 I$ & 79 & - \\
\hline & $h i s-2 I$ & $h i s-2 I$ & 80 & - \\
\hline \multirow[t]{2}{*}{4183} & met-2 & pur-I 5 & - & $\mathrm{P}$ \\
\hline & pur-1 5 & $p a l-15$ & $25^{*}$ & - \\
\hline \multirow[t]{2}{*}{4184} & $m e t-2$ & $p a l-I S$ & - & $\mathrm{P}$ \\
\hline & pur-I 5 & $p u r-15$ & $25^{*}$ & - \\
\hline 4 I 84 & $m e t-2$ & $t y r-8$ & - & 66 \\
\hline $4 I 83$ & met-2 & his-26 & - & 78 \\
\hline \multirow[t]{3}{*}{4155} & $\arg -40$ & $\arg -40$ & $4^{8}$ & - \\
\hline & $m e t-2$ & $\arg -40$ & 一 & 44 \\
\hline & met-2 & $\arg -40$ & - & 43 \\
\hline 4194 & met-2 & lelt-7 & - & 44 \\
\hline \multirow[t]{2}{*}{4191} & $m e t-2$ & $p u r-19$ & - & 44 \\
\hline & met-2 & $p u r-19$ & - & 41 \\
\hline \multirow[t]{2}{*}{4191} & met-2 & $h i s-28$ & - & 46 \\
\hline & met-2 & his-28 & - & 45 \\
\hline 4185 & ilv-3 & $i l v-3$ & $29^{*}$ & - \\
\hline 4186 & $i l v-3$ & $i l v-3$ & $30 *$ & - \\
\hline 4188 & met-2 & $i l v-3$ & - & $\mathrm{P}$ \\
\hline 4187 & met-2 & $i l v-3$ & - & $\mathrm{P}$ \\
\hline 4185 & $m e t-2$ & $h i s-27$ & - & 79 \\
\hline 4186 & $i l v-3$ & leu-6 & - & 46 \\
\hline 4188 & met-2 & ser-6 & - & 98 \\
\hline
\end{tabular}

$P$, Unselected markers which had reached high plateau values ( 80 to $100 \%$ ) indicative of early transfer or of close linkage to the selected marker.

* These markers are proximal to met-2 and appear to be closely linked; the intercept values were difficult to determine and are only approximate. 


\section{Mapping by interrupted mating}

Using the technique of interrupted mating, the times of entry of 19 markers carried by I 8 different recipient strains were determined. Both selected and unselected intercept values (Methods) were used in determining the earliest times of marker entry, which are shown in Table 3. Selected and unselected intercept values for markers were in good agreement, as were intercept values for the same marker in different strains. The two markers pur-I5 and ill-3 appeared to be proximal to met- 2 in that their intercepts obtained from direct selection were earlier (although this was not significantly so for $i l l-3$ ), but also in that $100 \%$ of selected $\mathrm{Met}^{+}$were also $\mathrm{Pur}^{+}$or $\mathrm{Ilv}^{+}$in the appropriate crosses; in addition, the only unselected intercept for met-2 was obtained from a pur- $15^{-}$selection. The marker ilv-4 (which determined a requirement for isoleucine only unlike ilv-3 which determined a requirement for isoleucine + valine) appeared to be distal to met-2 although closely linked to it. Six markers showed entry times in a cluster around $45 \mathrm{~min}$ among which was his-28; this was distinct from the remaining four His markers which had entry times around 80 min. The latest entering marker was ser- 6 at $98 \mathrm{~min}$.

In uninterrupted matings between MRE 4018 and MRE 4I 88 the ultimate terminal marker, integrated $\mathrm{F}$, could also be transferred. In a selection for $\mathrm{Ser}^{-}$recombinants, $28 \%$ were found to have inherited $\mathrm{Lac}^{+}$. The only class among these recombinants which could be tested for fertility was ser-6 met-2 ilv-3 $\mathrm{Lac}^{+}$and of these $80 \%$ proved to be fertile donors. A high proportion of recombinants, which proved to be donors, could also be obtained by selecting $\mathrm{Ser}^{+}$and $\mathrm{Lac}^{+}$jointly. The frequency of recombinants obtained for ser- 6 was about $\mathrm{I} / \mathrm{IO}^{5}$ donor bacteria, and the frequency with which integrated $\mathrm{F}$ could be transferred, was about $\mathrm{I} / 3 \times 10^{5}$ donor bacteria.

\section{Transfer of the streptomycin marker}

Four independently isolated SmR derivatives of MRE4I76 (met-2, pro-II, his-2I) were used as recipients in interrupted matings with the SmS donor MRE 4OI8. The numbers of selected $\mathrm{Met}^{+}$, $\mathrm{Pro}^{+}$and His recombinants recovered from the four recipients in the presence of streptomycin were about $50 \%$ of the numbers recovered in the absence of streptomycin from all interrupted samples. Analysis of Met progeny for the co-inheritance of $\mathrm{SmS}$ (selected in the absence of streptomycin) showed that $53 \%$ to $58 \%$ were $\mathrm{SmS}$ over a sampling range of 30 to $75 \mathrm{~min}$. These findings suggested that str was proximal to met-2.

When two SmR isolates (MRE 4197, 4I98) of donor MRE 40I8 were used in crosses with an SmS recipient (MRE 4200), it was found that 6 to $8 \mathrm{~h}$ of incubation in the absence of streptomycin was necessary for the segregation of SmR recombinants. Unselected analysis

Table 4. Analysis of SmR recombinants obtained from the cross MRE $4 \mathrm{I} 98 \times$ MRE 4200

Donor $\left(\mathrm{I} \times 10^{8}\right)$ and recipient $\left(3 \times 10^{8}\right)$ bacteria were impinged as a mixture on to five membranes and incubated from 15 to $75 \mathrm{~min}$ at $37 \mathrm{C}$. The bacteria, after removal from the membranes, were blended and spread on to $4 \mathrm{~cm}$ Oxoid membranes on plates supplemented with methionine, proline and histidine and incubated for $8 \mathrm{~h}$ at $28{ }^{\circ} \mathrm{C}$. The $4 \mathrm{~cm}$ membranes were then transferred on to the same media plus streptomycin and incubated for a further $36 \mathrm{~h}$ at $28{ }^{\circ} \mathrm{C}$. SmR recombinants were analysed for the unselected auxotrophic markers.

\begin{tabular}{|c|c|c|c|c|c|c|}
\hline Time $(\min ) \ldots$ & & I 5 & 30 & 45 & 60 & 75 \\
\hline \multirow{3}{*}{$\%$ of selected $s t r-24$ which were } & Met $^{+}$ & 0 & 0 & $10 \cdot 8$ & $26 \cdot 8$ & $34 \cdot I$ \\
\hline & Pro $^{+}$ & 0 & 0 & $\mathrm{I} \cdot 2$ & $4 \cdot 7$ & 5 \\
\hline & $\mathrm{His}^{+}$ & 0 & 0 & 0 & 0 & 4 \\
\hline
\end{tabular}




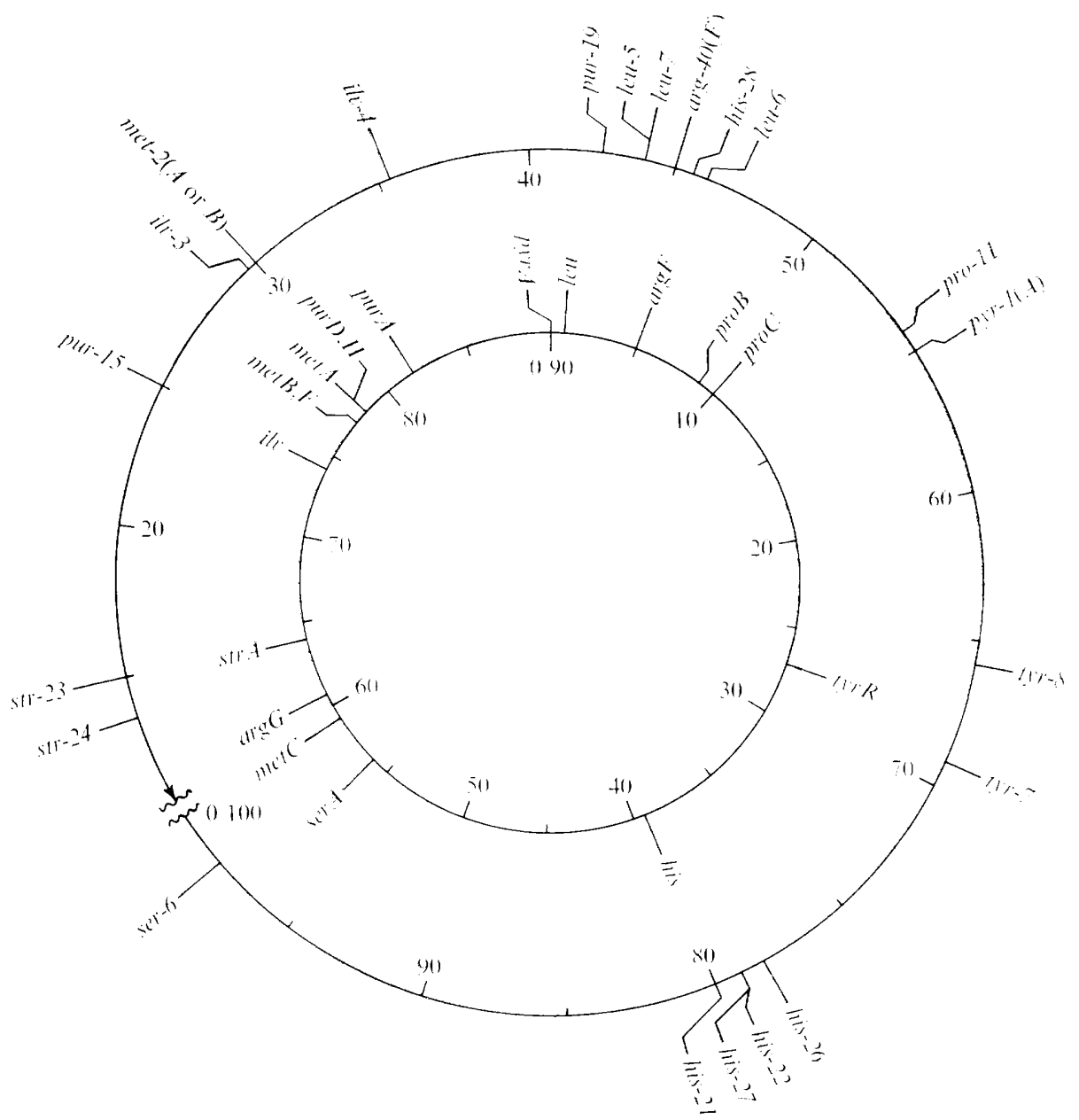

Fig. 2. The chromosome map of Yersinia pseudotuberculosis group A based on marker entry times (min) at $37 \mathrm{C}$. The broken part represents a postulated lag period prior to the onset of transfer. The inner map shows the positions of some of the equivalent loci in Escherichia coli (taken from the data of Taylor, 1970).

of such recombinants (Table 4) showed that met-2, pro-II and his-2I were distal to str-24. The intercept values obtained from direct selection for str-24 was $13 \mathrm{~min}$ and for $s t r-23$. $15 \mathrm{~min}$.

\section{Map construction}

The data contained in Table 3 together with that obtained for the transfer of $s t r-23$ and str-24 were used to construct a chromosome map of Yersinia pseudotuberculosis based on the entry times of the different markers at $37^{\circ} \mathrm{C}$. The map is shown in circular form in Fig. 2 and by way of comparison, the map of Escherichia coli (constructed from data of Taylor, 1970) is also shown. 


\section{DISCUSSION}

It was previously established (McMahon, 197I) that mating in crosses between strains of Yersinia pseudotuberculosis did not take place in broth culture at bacterial densities of $3 \times 10^{8} / \mathrm{ml}$ but that cell to cell contact on membranes was necessary. The present work shows that once mating had commenced, very vigorous methods of blending were necessary in order to separate mating pairs. By obtaining graded numbers of recombinants following the separation of mating pairs at different times, confirmation of the linear transfer of genes by a conjugation process in Yersinia pseudotuberculosis was obtained, a process analogous to that described by Matney \& Achenbach (1962) for Escherichia coli and by Sanderson \& Demerec (1965) for Salmonella typhimurium.

The map of Yersinia pseudotuberculosis (Fig. 2) resembles that previously constructed from the relative frequencies of marker transfer (McMahon, 197I). The most difficult markers to position accurately were pur-15, ilv-3 and ilv-4 because positioning depended on intercepts from direct selection only and although the intercept for pur-15 was different from met-2, that for ilv-3 was virtually identical. The conclusion that pur-15 and ill-3 were proximal to met-2 was based on the fact that the numbers of recombinants relative to time was always greater for these markers than for met-2. By similar reasoning, ilv-4 was thought to be distal to met-2.

Although the enzyme deficiencies for the mapped genes are not known, it is reasonable to deduce the probable loci involved from the growth responses of the mutants (McMahon, 1971) bearing them. Thus, met-2 was considered to be a met $A$ or $B, \arg -40$ to be an $\arg F$, pyr- $I$ (a one step mutation resulting in requirements for arginine + uracil) to be a cap mutant (Pierard, Glansdorff, Mergeay \& Wiame, 1965) and classified as a pyrA (Taylor, 1970). Strains bearing pur-15 and pur-I 9 have different growth requirements suggesting that the loci involved are different; likewise $i l v-3$ and $i l v-4$ are probably non-allelic. A comparison of the two maps in Fig. 2 shows that all the markers in Yersinia pseudotuberculosis, with the exception of pur-19 and pyr-I, are comparable with those of Escherichia coli. It would appear that his-28 is a second his locus which is not present in E. coli.

No direct evidence was obtained to confirm the circularity of the chromosome since transfer was promoted from one site only and donors, having different sites of integration, were not obtained (unpublished). However, the results indicate both a single linkage group and the transfer of the fertility factor as an integrated terminal marker, a situation analogous to that found in Escherichia coli. These similarities indicate that the chromosome of Yersinia pseudotuberculosis may also be circular. Pemberton \& Holloway (1972) have reported a single linkage group for Pseudomonas aeruginosa but, unlike the present work, found no similarities to the $E$. coli map.

If the assumption is made that the chromosome of Yersinia pseudotuberculosis is circular and the comparison with Escherichia coli as shown in Fig. 2 is meaningful, then the origin of donor MRE 4018 should lie between 57 and $64 \mathrm{~min}$ in terms of the E. coli map. Donor MRE 4OI 8, when used with a group D recipient (MRE 229I), was able to transfer a presumed $\arg G$ as a lead marker and a presumed met $C$ as a terminal marker (unpublished). This would position the origin between 59 and $6 \mathrm{I}$ min. Since the estimated position of the origin is approximately I min from time o on the map, it was postulated that this constituted a lag period before transfer commenced following impingement on membranes.

I am indebted to Dr T. W. Burrows for most helpful discussion and to Mr P. E. Stone for his excellent technical assistance. 


\section{REFERENCES}

Demerec, M., Adelberg, E. A., Clark, A. J. \& Hartman, P. E. (i968). A proposal for a uniform nomenclature in bacterial genetics. Journal of General Microbiology 5o, r-r4.

Lawton, W. D., Morris, B. C. \& Burrows, T. W. (1968). Gene transfer in strains of Pasteurella pseudotuberculosis. Journal of General Microbiology 52, 25-34.

Lawton, W. D. \& Stull, H. B. (1971). Chromosome mapping of Pasteurella pseudotuberculosis by interrupted mating. Journal of Bacteriology ro5, $855^{-863}$.

McMahon, P. C. (197I). High frequency gene transfer in Pasteurella pseudotuberculosis. Journal of General Microbiology 69, 405-415.

Matney, T. S. \& AChenbach, N. E. (1962). A comment on the fertility of $F_{2}$ donor types of Escherichia coli K12. Biochemical \& Biophysical Research Communications 9, 285-287.

Morris, B. C. \& Burrows, T. W. (1968). Gene transfer studies with Pasteurella pseudotuberculosis. International Symposium on Pseudotuberculosis, Paris, 1967. Symposis Series-Immunobiological Standardization $9,275-284$.

Pemberton, J. M. \& Holloway, B. W. (1972). Chromosome mapping in Pseudomonas aeruginosa. Genetical Research 19, $25 \mathrm{I}-260$.

Pierard, A., Glansdorff, N., Mergeay, M. \& Wiame, J. M. (1965). Biosynthesis of carbamoyl phosphate in Escherichia coli. Journal of Molecular Biology 14, 23-36.

Sanderson, K.E. \& Demerec, M. (1965). The linkage map of Salmonella typhimurium. Genetics $5 \mathbf{x}$, $897-9$ I3.

TAYLOR, A. L. (1970). Current linkage map of Escherichia coli. Bacteriological Review's 34, I 55-I75.

Wollman, E. L. \& JaCOB, F. (I955). Sur le mécanisme du transfert de matériel génétique au cour de la recombinaison chez Escherichia coli $\mathrm{K}-\mathrm{I} 2$. Comptes rendus de l'Académie des sciences 240, 2449-245 I.

Wollman, E. L. \& JACOB, F. (1958). Sur les processus de conjugaison et de recombinaison chez Escherichia coli. V. Le mechanisme du transfert de material génétique. Annales de l'Institut Pasteur 95, 64I-666 